REFLECTIONS

\title{
A Daughter's Duty
}

\author{
Terry L. Wahls, MD, MBA $1,2,3,4$ \\ ${ }^{1}$ Center for Research in the Implementation of Innovative Strategies in Practice, lowa City, IA, USA; ${ }^{2}$ Internal Medicine, VA lowa City Health \\ Care System, lowa City, IA, USA; ${ }^{3}$ Department of Internal Medicine, University of lowa, lowa City, IA, USA; ${ }^{4}$ lowa City VA Medical Center, lowa \\ City, IA, USA.
}

J Gen Intern Med 23(6):887-8

DOI: $10.1007 / \mathrm{s} 11606-007-0465-0$

(c) Terry L. Wahls 2007

$\mathrm{M}$ om calls me, worried about my dad. She thinks his pain is getting steadily worse and he has fallen again. I tell her Zach and I will drive down on Friday.

I finish clinic and drive the 4 hours back to Iowa. My dad had hip replacement surgery 2 months earlier, and I expect he would be a little slow yet. But when I see him, I am alarmed. My mother is right. He is looking much weaker than I remembered.

My dad tells me he had kept his postop check-up with the doctor, but my dad is disgusted with the visit. His doctor had only scolded him for getting weaker instead of stronger. Mom confirms that the physical therapist had been working with my dad. She wants to know what I think. But when I tell them he needs to see a specialist, my dad refuses.

"There aren't any here."

"What about Iowa City?" I ask.

"No." My dad closes his eyes.

I try again, "Mayo Clinic?"

My mom, clumsy, frustrated, says “John, why won’t you

agree? Terry can help."

Oblivious to their arguing, Zach starts to tap Grandpa's knee with his little hammer. My dad opens his eyes and pulls him onto his lap.

My mom turns to me, shrugging her shoulders, and says, "Save your breath. Nothing is going to change his mind." She is right. I should give it up.

Grandpa and Zach intently scrutinize each piece of paper Zach pulls out of Grandpa's shirt pocket. I smile thinking that this should be on film. I set up my video camera and begin recording. Zach slides off his knee and runs into the kitchen.

I keep the camera rolling and say, "Can I ask you a few questions? Maybe you can give Zach advice for later years.” He agrees.

My dad speaks to the future Zach about chores, handling money, and even dating. This is priceless. Story telling is one of my father's particular gifts. Focusing on someone else I hope will ease his pain. Perhaps a grandson is the best medicine I can offer.

Received August 7, 2007

Accepted October 29, 2007

Published online December 13, 2007
My dad does not want to see more specialists. He just wants to keep farming, and while he is done trying to figure it out, I am not. It is my obligation to keep trying to help, just as they had helped their parents. I tell Mom I will come back next weekend, but I wish I could do more.

As I am packing the car to go back to Wisconsin, my father falls and dislocates his hip. We call an ambulance. While they take my dad to the local hospital, I call the orthopedic surgeon on call in my hospital and facilitate my father's transfer to the hospital I attend in Marshfield.

Once my dad is in my hospital, I handpick his doctors. My friend, Wayne, agrees to be my dad's Internal Medicine doctor while he is in the hospital. Wayne and I then select our very best people to see him. They try test after test, scan after scan, but an explanation for his pain and weakness is not easy to find.

Every morning, first thing, I stop by his room. Then I go on to see my hospital patients, attend meetings, and my morning clinic. Nearly always, I go to see him over lunch. After work, my nanny brings Zach to my dad's room and we have supper together. Once Zach gets restless, I take him home.

Every couple of days someone new arrives to take Mom to check on the farm, or back here to be with Dad. I am exhausted by all of the company, but of course, everyone stays at my house. My mom is tired by this, too, and has the farm to manage as well. I do not complain.

Four long weeks my dad is in the hospital. The diagnosis is Mononeuritis Multiplex, a disease affecting his peripheral nerves. In spite of the big workup, all the scans, blood tests, procedures, and consultations, no cause is found.

Eventually, the neurologist tells him to try high-dose Cytoxan. After he has taken it for 5 days, he is transferred to the Rehabilitation Wing. Then the therapists and doctors tell him it is not safe to walk. My father is angry, feeling betrayed. He knows he must not stop or he would never walk again. His doctors again tell him it is not safe. Then they tell my mom to take away all of his crutches, canes, and walkers, as if that would take away his desire to walk.

She shakes her head. When we get home, she asks what I think. How will my dad react, if the crutches are gone? I worry, wondering how Mom will manage when my dad is home.

In the midst of all that commotion with my father in the hospital is Zach's second birthday. My friends kindly help us throw a backyard party to celebrate. We even manage to bring my dad out to join us.

The next morning my dad's best friend, Sylvester, drives my mom back to the farm. She needs to get things ready because Dad is going home in just 2 days. Sylvester says he will be back to pick my dad up and take him home. 
Worried about them both, I call around and find someone willing to stay overnight a couple nights a week. Our neighbor's boy, now a grown man, and a family friend, agrees to do this. I am relieved, this should make it much easier for my dad to accept.

When I tell Dad, he is resolutely opposed to the idea. I tell him that Mom cannot stay up night after night. I say that she will need a couple nights of rest each week, but my dad does not see it that way. He expects her to wait on him, take care of him. It is a wife's duty to her husband; it is her lot in life to care for him. She will just have to cope with less sleep. We argue, but it does not help. We are both getting angry and are saying things we probably do not mean. Finally, I simply walk out and go home.

Although I usually stop in to see my dad first thing, due an early meeting, I have not been by his room yet. The overhead page announces a code, but I am not carrying the code beeper so I can ignore it. Then I am paged. I dial the number and keep writing.

"2 South, Rehab," answers the clerk.

"Good morning, this is Dr. Wahls. I was paged."

"Dr. Wahls, we are coding your father."

"No!" Involuntarily, a muffled cry escapes. I drop the phone, knocking charts to the floor in my haste as I jump up and run out of the nurses' station.

Rehab is a long way off. As I run, my mind races, thinking about what must have happened. Likely, it was the narcotics. They must have suppressed his breathing enough to cause a respiratory arrest. Maybe it was a medication error. That would not surprise me, given the severity of his pain. Narcan, which reverses narcotics, should easily take care of that; he will be breathing again on his own right away. Even so, he would still need to stay in the ICU for a while. How is he going to cope with ICU? How will I cope?

When I finally arrive on the rehab unit, I run past the empty nurse's station to his room. The door is open. However, when I enter his room, I see and stop. Slowly, I back out and lean against the wall, crying.

A nurse comes out of his room and guides me to a chair. I weep. She leaves. Then I see my friend Wayne walk, grim faced, into my father's room.

A few minutes later, I hear new steps coming down the hall. It is my medical assistant, Barb, and my friend Sue, who is also the head of our department. They sit with me and I tell them I had not followed my usual routine.

"Usually I see him first, before anything else, but I was running late. I went to my meeting and decided to see him after rounding."

"You wouldn't have known."

"Don't blame yourself."
I weep, remembering last night, walking out on my father. That should not have been the last thing I had done with him. My thoughts race as my tears fall.

It never occurred to me; my father could die. Sixty-five is young anymore. Most of my patients do not die in their sixties or even seventies unless there is something significantly wrong, like diabetes, heart disease, kidney failure, or cancer. He may have had this terrible neuropathy, but otherwise his health is good. There is no reason to think he might die from it.

My friends are talking, trying to comfort me. But what solace can their words provide me? Sue touches my knee, telling me it has been over an hour. She is going to check on how things are going. I watch her stand and walk into my father's room. A few minutes later, she returns.

It is not looking good. He has been coded for more than ninety minutes, but no one wants to stop. Everyone on that code team knows you.

I grit my teeth, trying to stay in control. Sue waits for me to collect myself. Then she picks up my hands, looking in my eyes and gently says, "Wayne is your friend. He can't stop coding him either." Barb puts her arm around my shoulders and squeezes. Slowly, carefully, Sue adds, "Wayne is going to come to talk to you in a few minutes. Remember when he does how long they've been working on your dad."

A few minutes later, Sue stands and Wayne sits in her place. Tears are streaming down his face. I wait for him to speak.

"It has been too long and he was not going to come back." His voice cracks. He pauses to collect himself. Quietly, he says, "We have done what we could." I nod. He gives me a hug, tears streaming down his face and mine.

After Wayne leaves, something very unusual happens. The residents on the code team come, one by one, to speak with me. They apologize for failing to revive my father, crying as they speak, having learned that coding strangers is easy. Coding friends and family is not.

They leave, and I sit down again, waiting once more. When the nurse tells me I can go to see him, I stand, take her hand, and walk back into his room. I sit next to him, finding comfort sitting there with him, remembering, and mourning. Then, in spite of myself, I find myself again wondering, what if I had seen him first this morning...

But now it is too late. Holding his hand, wishing he could hear me, I say aloud words I had not spoken before. I study his face, trying to remember a lifetime.

Then, leaning over, I kiss his forehead, and say good-bye.

He had been right. We could not stop his pain. 